\title{
СТАТТЯ 5 КОНВЕНЦІЇ ПРО ЗАХИСТ ПРАВ ЛЮДИНИ І ОСНОВОПОЛОЖНИХ СВОБОД: ПРАКТИКА ЄСПЛ
}

\begin{abstract}
Анотація. Стаття присвячена дослідженню практики ЄСПЛ щодо порушень по статті 5 Конвенції про захист прав людини і основоположних свобод (Право на свободу і особисту недоторканність). Представлені рішення Свропейського суду з прав людини, які розкривають мету статті 5; тлумачення принципу правової визначеності у категорії судових справ, які пов'язані з правом на свободу, якості закону, забороні свавільному арешту тощо. Автор звертае увагу на те, що поняття «свавілля» у статті 5 п. 1 мае білыш широке значення, аніж просто недотримання національного законодавства. Позбавлення волі може бути законним з точки зору внутрішнього права, але все ж свавільним в розумінні Конвенщії, порушуючи тим самим її положення (Creangă v. Romania, § 84). Практика ЄСПЛ щодо тримання особи під вартою на підставі обвинувального вироку без конкретних підстав, передбачених національним законодавством $\epsilon$ порушенням статті 5 п. 1 (Baranowski v. Poland). Це стосуеться і практики автоматичного продовження попереднього ув'язнення без будь-яких законних підстав (Svipsta v. Latvia). Крім того, автор наводить приклади практики ЄСПЛ щодо відсутності або недостатнього обтрунтування рішень судів про обмеження свободи осіб та про тримання осіб під вартою; звертає увагу на те, що одним із елементів, який враховуеться ЄСПЛ при оцінці законності тримання під вартою згідно зі статтею 5 п. 1 є мотиви рішення суду. Відсутність будь-яких підстав у рішеннях судових органів, які санкціонують тримання під вартою протягом тривалого періоду часу, може бути несумісним з принципом захисту від свавілля, закріпленим у статті 5 § 1 (Stašaitis v. Lithuania).
\end{abstract}

Ключові слова: право на свободу, позбавлення волі, свавілля, національний суд, ЄСПЛ, строки тримання осіб під вартою, інтрузивні заходи, Covid-19.

Bila-Kyselova Anna

Bilozerskyi Raion Court of Kherson Oblast

\section{ARTICLE 5 OF THE CONVENTION FOR THE PROTECTION OF HUMAN RIGHTS AND FUNDAMENTAL FREEDOMS: THE CASE LAW OF THE ECHR}

Summary. The article examines the case law of the European Court of Human Rights on violations of Article 5 of the Convention for the Protection of Human Rights and Fundamental Freedoms (Right to liberty and security of person). The judgments of the European Court of Human Rights are presented, which reveal the purpose of Article 5; interpretation of the principle of legal certainty in the category of cases related to the right to liberty, the quality of the law; prohibition of arbitrary arrest, etc. The author draws attention to the fact that the concept of "arbitrariness" in Article 5, paragraph 1 has a broader meaning than simply non-compliance with national law. Imprisonment may be lawful under domestic law, but still arbitrary within the meaning of the Convention, thereby violating its provisions (Creangă v. Romania, § 84). The ECHR's practice of detaining a person on the basis of a conviction without specific grounds under national law is a violation of Article $5 \S$ 1 (Baranowski v. Poland). This also applies to the practice of automatically extending pre-trial detention without any legal grounds (Svipsta v. Latvia). Having proclaimed the right to liberty in Article 5 of the Convention, the international community has stated that it recognizes the physical freedom of every human being and the inviolability of the human person. At the same time, the goal and plan for the implementation of international obligations by states should be to ensure not illusory promises to man, but real freedom and rights, as well as to prevent restrictions on freedom contrary to the law. It is important to understand that "detention" is a lawful measure if such a restriction of human rights and freedoms is based on a reasonable court decision. Yes, courts should keep in mind that less intrusive measures than detention should always be considered. It is concluded that the European Court of Human Rights recommends adherence to international agreements in matters relating to the protection of the right to liberty and security of person. In the process of analyzing the practice of the ECHR, the following decisions are presented: Kurt v. Turkey, Stašaitis v. Turkey Lithuania, Svipsta v. Latvia, Nikolov v. Bulgaria, Г.K. v. Poland, Mooren v. Poland, Germany, Medvedyev and Others v. Germany France, Creangă v. France Romania, Baranowski v. Romania Poland, etc., which demonstrate the position of the international institution and determine the direction of the work of national human rights.

Keywords: right of liberty, imprisonment, arbitrariness, national court, ECHR, terms of detention of persons, intrusive measures, Covid-19.

$\Pi^{\circ}$ остановка проблеми. Ідея про права людини та їх подальший розвиток є чи не найбільшими досягненнями людської цивілізації. Не зменшуючи значення відмінностей у народів та націй, все ж можна цілковито погодитися з твердженням, що саме визнання і забезпечення прав людини е тими критеріями, за допомогою яких ми можемо говорити про рівень розвитку суспільства та держави. Право на свободу та особисту недоторканість - це право не бути підданим свавільному арешту та жахливим варварським актам насильства, які несумісні з людською гідністю.

Право на свободу та особисту недоторканність, передбачене в статті 5 Конвенції про захист прав людини і основоположних свобод (далі - Конвен- 
ція) [1]. Свропейський суд з прав людини (далі ЄСПЛ) неодноразово підкреслював свою позищію про те, що метою статті 5 Конвенщії є запобігання свавільному або необгрунтованому позбавленню волі. При цьому, поняття «свавілля» у п. 1 статті 5 Конвенції має більш широке значення, ніж просто недотримання національного законодавства.

Крім того, аналіз практики міжнародного судового органу надає підстави зазначити про те. що ЄСПЛ вважає, що тлумачення та застосування нащіонального права $є$ прерогативою національних судів. Та, коли реалізація міжнародних зобов'язань за Конвенцією порушуеться та виникають проблеми щодо забезпечення прав і свобод людини, тоді ССПЛ перевіряе порядок дотримання п. 1 статті 5.

Аналіз останніх досліджень та публікацій. Дослідженням забезпечення прав і свобод людини та вивченням практики ССПЛ займаються науковці та судді Т. Анцупова, I. Гловюк, М. Дерев’янко, П. Рабінович та інші. Разом з тим, дослідження сучасної практики ЄСПЛ та дотримання виконання міжнародних домовленостей по статті 5 Конвенції (Право на свободу і особисту недоторканність) потребуе уточнення.

Виділення невирішених раніше частин загальної проблеми. Практика Свропейського суду 3 прав людини має на меті забезпечити захист прав людини реальний, а не ілюзорний. Держави, які погодилися визнавати міжнародні домовленості взяли на себе відповідальність забезпечити кожній особі дотримання прав і свобод. Тому, тлумачення міжнародною інституцією норм, які забезпечують право на свободу і особисту недоторканність з урахуванням сучасних змін, викликів та технологій мають використовувати національні суди в своїй практиці. Разом 3 тим, сучасна практика ЄСПЛ вносить корективи у вже існуючу практику інституції та потребує дослідження.

Метою статті є: аналіз практики ЄСПЛ по статті 5 Конвенції (Право на свободу і особисту недоторканність) та надання інформації про перелік рішень, які демонструють позицію міжнародної установи та визначають вектор напрямку роботи національних органів для дотримання прав людини.

Виклад основного матеріалу. Відповідно до п.1 статті 5 Конвенції: «кожен має право на свободу та особисту недоторканність. Нікого не може бути позбавлено свободи, крім таких випадків і відповідно до процедури, встановленої законом: а) законне ув'язнення особи після засудження її компетентним судом; b) законний арешт або затримання особи за невиконання законного припису суду або для забезпечення виконання будь-якого обов'язку, встановленого законом; с) законний арешт або затримання особи, здійснене 3 метою допровадження ï до компетентного судового органу за наявності обгрунтованої підозри у вчиненні нею правопорушення... е) законне затримання осіб для запобігання поширенню інфрекційних захворювань...» [1].

Тож, основною метою статті 5 Конвенції є запобігання свавільному або необірунтованому позбавленню волі.

ЄСПЛ зазначив, що «право на свободу та особисту недоторканість має найважливіше зна- чення в «демократичному суспільстві» за змістом Конвенції» (Medvedyev and Others v. France) [2].

Слід зазначити, що стаття 5 Конвенщї застосовуеться до будь-якого затримання (тримання під вартою), яке передбачає позбавлення волі, та не передбачає відмінностей залежно від юридичного характеру правопорушення, у скоєнні якого особу було визнано винною за національним законом відповідної держави.

Розглядаючи термін «правопорушення», слід звернути увагу на те, що таке правопорушення має самостійне значення та може бути ідентичним за національним законом як:

- кримінальне правопорушення;

- адміністративне правопорушення;

- дисциплінарне правопорушення.

В умовах поширення Covid-19 може бути виправданим затримання осіб, які можуть бути потенційними носіями хвороби, адже саме люди $є$ джерелом розповсюдження інфекційних захворювань. Обстави, які виправдовують дії держави полягають в тому, що особу може бути позбавлено волі для того, щоб:

а) надати їй медичну допомогу;

б) виконати обов'язок перед суспільством щодо захисту населення від інфекційних хвороб;

c) забезпечити потреби суспільства на безпечне життя та продовження людського роду.

Крім того, слід зазначити, що таке затримання осіб $є$ виправданим не тільки тому, що вони можуть становити загрозу для громадської безпеки, а й тому, що таке затримання та подальше лікування може відповідати власним інтересам людини.

Таким чином, основними критеріями при оцінці «законності» затримання особи для запобігання поширенню інфекційних захворювань можна назвати наступні:

1.Загроза поширення інфекційних захворювань здоров'ю (безпеці) населення.

2. Затримання інфікованої особи для того, щоб запобігти поширенню хвороби, адже менш жорсткі заходи є недостатніми для захисту суспільних інтересів.

Розглянемо приклади рішень ЄСПЛ, які можуть допомогти національним судам при застосуванні норм права пов'язаних з затриманням осіб.

На думку ЄСПЛ, «відсутність обліку таких даних, як дата, час і місце затримання, ім'я затриманого, причини затримання та ім'я особи, яка провадила це затримання повинні розглядатися як несумісні, зокрема 3 самою метою статті 5 Конвенціï» (Kurt v. Turkey, § 125; Anguelova v. Bulgaria, § 154) [3, 4]. Це також суперечить вимогам законності згідно з Конвенцією (Anguelova v. Bulgaria) [4]. При цьому, «невизнання державою тримання особи під вартою є запереченням принципово важливих гарантій, що містяться у статті 5 Конвенщії, та являє найтяжче порушення ціеї норми».

Для того, щоб тримання під вартою відповідало вимогам законності, така процедура має відповідати діючим нормам національного права: «відповідно до процедури, передбаченої законом». Це означає, що тримання під вартою має відповідати матеріальним і процесуальним нормам нащіонального права (чи міжнародного права), коли це доречно (Medvedyev and Others v. France, [ВП], § 79) [2]. 
Так, в рішенні G.K. v. Poland ЄСПЛ встановив, що мало місце порушення статті 5 Конвенції, де органи влади не подали заяви про продовження дії документу про тримання під вартою протягом терміну, встановленого законом (п. 76) [5]. 3 іншого боку, рішення по справі Talat Tepe v. Turkey демонструе наступне: «порушення розпорядження щодо способу проведення розслідування певних видів злочинів не позбавило чинності правові підстави для арешту та подальшого тримання під вартою, передбачені національним законодавством» (п. 62) [6].

Міжнародний судовий орган вважає, що хоча тлумачення та застосування національного права $е$ в першу чергу прерогативою органів державної влади, особливо судів, ситуація е іншою у випадках, коли недотримання такого законодавства тягне за собою порушення Конвенції. У випадках, коли розглядається питання щодо дотримання п. 1 статті 5 Конвенції, «Суд повинен здійснювати певні повноваження щодо перевірки дотримання національного законодавства» (Creangă v. Romania, [ВП], §101) і «враховувати правові норми у відповідний момент» (Włoch v. Poland, § 114) [7, 8].

ЄСПЛ наголошуе на дотриманні державами принципу правової визначеності. У ситуаціях з позбавленням волі важливим $е$ дотримання загального приниипу правової визначеності.

Таким чином, важливо, щоб умови позбавлення волі були чітко визначені у національному законодавстві, і щоб закон був передбачуваним у своєму застосуванні для того, щоб дотримати стандарт «законності», який встановлений Конвенщією та вимагає, щоб всі закони були точними та дозволяли людині (в разі необхідності користуючись порадою) в розумній мірі та за певних обставин передбачити наслідки, які можуть бути результатом конкретних дій (Creangă v. Romania, § 120; Medvedyev and Others v. France, [BП], § 80) [2, 7].

Практика тримання особи під вартою на підставі обвинувального висновку без будь-яких конкретних підстав, передбачених національним законодавством (правозастосовною практикою) е порушенням статті 5 п. 1 (Baranowski v. Poland, §§ 50-58) [9].

ЄСПЛ своєю практикою підтверджуе й те, що порушення прав людини буде й тоді, коли автоматично продовжуеться попередне ув'язнення без будь-яких законних підстав (Svipsta v. Latvia, $\S 86)$ [10]. Разом з тим, ЄСПЛ у справі Laumont v. France зазначив наступне: «тривале тримання особи під вартою на підставі розпорядження Обвинувальної палати, яке вимагало подальшого слідства, без винесення формальної постанови про взяття під варту не було визнано порушенням цієї статті (§ 50)» [11].

У справі Nasrulloyev v. Russia ЄСПЛ звернув увагу на те, що "положення, які тлумачаться національною владою непослідовним та взаємовиключним чином, так само не відповідають стандарту «якості закону», передбаченому Конвенцією» (§ 77) [12].

За відсутності правозастосовної практики, компетенція ЄСПЛ не розповсюджується на тлумачення національного законодавства, а тому міжнародна установа може не дійти висновку про порушення національними судами процедури, передбаченої законом (Włoch v. Poland, §§ 114-116) [8].

Що стосуеться дипломатичних нот, то ЄСПЛ звернув увагу на таке: «хоча дипломатичні ноти є джерелом міжнародного права, затримання екіпажу на основі таких нот не є законним відповідно до змісту п. 1 статті 5 Конвенції, якщо вони не $є$ досить точними і передбачуваними. Зокрема, відсутність конкретного посилання на потенційний арешт та тримання під вартою членів екіпажу е порушенням вимоги правової визначеності та передбачуваності згідно 3 п. 1 статтею 5 Конвенції (Medvedyev and Others v. France, [ВП], §§ 96-100) [2].

Henpunycmuлість свавілля. Слід також відзначити, що будь-яке позбавлення волі мае узгоджуватися з метою захисту особи від свавільного порушення прав відносно свободи людини.

Поняття «свавілля» за п. 1 статті 5 Конвенції мае «більш широке значення, аніж просто недотримання національного законодавства, так що позбавлення волі може бути законним з точки зору внутрішнього права, але все ж свавільним в розумінні Конвенції, порушуючи тим самим їі положення» (Creangă v. Romania, § 84) [7].

Оперативність розгляду справи. Вивчаючи питання щодо дотримання права людини на свободу, слід зазначити й про швидкість реагування, з якою національні суди мають діяти коли закінчуеться строк дії рішення про тримання під вартою.

Так, ЄСПЛ вважае (в контексті підпункту (c)), що період тривалістю менше місяця між закінченням дії первісного рішення про тримання під вартою та видачею нового, обгрунтованого рішення про тримання під вартою, який слідуе за поверненням справи з апеляційного суду до суду нижчої інстанції, не дає підстав вважати тримання заявника під вартою свавільним (Minjat v. Switzerland, §§ 46, 48) [14].

Разом з тим, проаналізувавши рішення по справі Khudoyorov v. Russia було встановлено, що «період часу більше року після повернення справи апеляційним судом до суду нижчої інстанції, коли заявник перебував в стані "невизначеності» щодо підстав для його ув'язнення в поеднанні з відсутністю встановленого строку, протягом якого суд нижчої інстанції повинен переглянути питання його тримання під вартою, дозволяе визнати таке тримання заявника під вартою як свавільне» (§136) [15].

Слід звернути увагу на те, що «тримання під вартою» $е$ «законним», якщо таке обмеження прав людини базуеться на постанові суду.

Постанови про тримання під вартою ЄСПЛ було визнано недійсними ex facie у справах, коли зацікавлену сторону:

- не було належним чином повідомлено про слухання (Khudoyorov v. Russia, § 129);

- національні суди не провели розслідування відносно (фінансових) засобів відповідно до вимог національного законодавства (Lloyd and Others v. the United Kingdom, $\S \S 108$, та 116);

- суди нижчого рівня не розглянули належним чином альтернативи тюремному ув'язненню (Lloyd and Others v. the United Kingdom § 113) [15; 16].

Обгрунтування рішення суду. Відсутність або недостатність обтрунтування в постановах 
про тримання під вартою є одним 3 елементів, який враховуеться Судом при ощінці законності тримання під вартою згідно 3 п. 1 статті 5.

Таким чином, ЄСПЛ говорить про наступні дефекти в рішеннях судів, які можуть привести до встановлення міжнародною інституцією порушень:

- відсутність будь-яких підстав у рішеннях судових органів, які санкціонують тримання під вартою протягом тривалого періоду часу є несумісне $з$ принципом захисту від свавілля, закріпленим у статті 5 (Stašaitis v. Lithuania).

- коротке рішення, у якому відсутні посилання на правові положення, які дозволяли б тримання під вартою, не може забезпечити достатнњого захисту від свавілля (Khudoyorov v. Russia, § 157) [15; 17].

Разом $з$ тим, ЄСПЛ дійшов висновку про те, що тримання заявника під вартою, відповідає вимогам нащіонального законодавства, незважаючи на відсутність причин у постанові про тримання під вартою, адже національні суди знайшли підтвердження тому, що для попереднього ув'язнення заявника існували певні підстави (Minjat v.Switzerland, § 43) [14].

Крім того, у випадках, якщо національні суди скасовували постанову про затримання через відсутність обгрунтування, але при цьму визнавали, що для тримання заявника під вартою існували деякі підстави, відмова у винесенні постанови про звільнення особи, яка тримається під вартою, та направлення справи у суд нижчого рівня для визначення законності тримання під вартою не становили порушення п. 1 статті 5 Конвенції. При цьму, ЄСПЛ наголошував, що необхідно, щоб рішення про тримання під вартою містило конкретні підстави та встановлювало конкретні граничні строки (Meloni v. Switzerland, § 53) [18].

Також, ЄСПЛ звернув увагу у справі Ambruszkiewicz v. Poland на те, що «суди мають розглянути можливість застосування менш інтрузивних заходів, ніж тримання під вартою» (§ 32) [19].

Проаналізувавши практику ЄСПЛ нами були виявлені судові рішення, які становлять приклади процесуальних порушень, але були визнані такими, що не тягнуть за собою незаконності тримання заявника під вартою:
- Справа Marturana v. Italy. Неповідомлення звинуваченого про постанову про тримання під вартою не було визнано "грубим або очевидним порушенням» в розумінні практики Суду, оскільки органи влади дійсно вважали, що заявника було повідомлено про постанову;

- Справа Nikolov v. Bulgaria. Звичайна канцелярська помилка в постанові про взяття під варту або тримання під вартою, яку було пізніше виправлено органом судової влади;

- Справа Gaidjurgis v. Lithuania. Заміна підстав для тримання заявника під вартою з огляду на фракти, зазначені судами на підтримку своїх висновків (Gaidjurgis v. Lithuania) [20, с. 10].

Висновки та пропозиції. ЄСПЛ з прав людини рекомендує дотримуватися міжнародних домовленостей в питаннях, які стосуються забезпечення права на свободу та особисту недоторканність.

Проголосивши право на свободу у статті 5 Конвенції міжнародна спільнота зазначила про те, що визнає фрізичну свободу кожної людини та недоторканість людини. При цьому, мета та план реалізації державами міжнародних зобов'язань мають полягати в тому, щоб забезпечити не ілюзорні обіцянки людині, а реальну свободу та права, а також не допустити обмеження свободи в супереч закону. Важливо розуміти, що «тримання під вартою» є законним заходом, якщо таке обмеження прав і свобод людини базуеться на обгрунтованому рішенні суду. Разом з тим, суди мають пам'ятати, що слід завжди розглядати можливість застосування менш інтрузивних заходів, ніж тримання під вартою.

У процесі аналізу практики ССПЛ представлені рішення: Medvedyev and Others v. France, Stašaitis v. Lithuania, Kurt v. Turkey, Svipsta v. Latvia, Anguelova v. Bulgaria, Ambruszkiewicz v. Poland, Nasrulloyev v. Russia, Baranowski v. Poland, Minjat v. Switzerland, Lloyd and Others v. the United Kingdom, які демонструють позицію міжнародної установи та визначають вектор напрямку роботи національних органів для дотримання прав людини у площині «свобода, недоторканість, «ні свавіллю!»».

\section{Список літератури:}

1. Конвенція про захист прав людини і основоположних свобод від 04.11.1950. URL: https://zakon.rada.gov.ua/ laws/show/995_004/ed19900101

2. Рішення у справі Medvedyev and Others v. France. URL: https://sherloc.unodc.org/cld/case-law-doc/ drugcrimetype/eu/2010/medvedyev_and_others_v_france.html

3. Рішення у справі Kurt v. Turkey. URL: https://www.refworld.org/cases,ECHR,49997ae512.html

4. Рішення у справі Anguelova v. Bulgaria. URL: https://hudoc.echr.coe.int/fre\#\{\%22itemid\%22:[\%22001-81906\%22]\}

5. Рішення у справі G. K. v. Poland. URL: https://hudoc.echr.coe.int

6. Рішення у справі Talat Tepe v. Turkey. URL: https://www.gardencourtchambers.co.uk/wp-content/uploads/ 2015/09/CASE-OF-KAYTAN-v.-TURKEY.pdf

7. Рішення у справі Creangă v. Romania. URL: https://www.legal-tools.org/doc/fd9acb/pdf/

8. Рішення у справі Włoch v. Poland. URL: https://swarb.co.uk/wloch-v-poland-no-2-echr-10-may-2011/

9. Рішення у справі Baranowski v. Poland. URL: https://hudoc.echr.coe.int/fre\#\{\%22itemid\%22:[\%22001-82496\%22]\}

10. Рішення у справі Svipsta v. Latvia. URL: https://hudoc.echr.coe.int/fre\#\{\%22itemid\%22:[\%22001-72749\%22]\}

11. Рішення у справі Laumont v. France. URL: https://swarb.co.uk/laumont-v-france-echr-8-nov-2001/

12. Рішення у справі Nasrulloyev v. Russia. URL: https://www.refworld.org/pdfid/473ac7512.pdf

13. Рішення у справі Minjat v. Switzerland. URL: https://hudoc.echr.coe.int/fre\#\{\%22sort\%22:[\%22EMPTY\%22],\%2 2itemid\%22:[\%22001-65961\%22]\}

14. Рішення у справі Khudoyorovv. Russia. URL: https://europeancourt.ru/resheniya-evropejskogo-suda-na-russkomyazyke/xudoerov-protiv-rossii-postanovlenie-evropejskogo-suda/

15. Рішення у справі Lloyd and Others v. the United Kingdom. URL: https://swarb.co.uk/lloyd-and-others-v-theunited-kingdom-echr-1-mar-2005/

16. Рішення у справі Stašaitis v. Lithuania. URL: https://brill.com/view/journals/hudi/13/3-4/article-p283.xml 
17. Рішення у справі Meloni v. Switzerland. URL: https://hudoc.echr.coe.int

18. Рішення у справі Ambruszkiewicz v. Poland. URL: https://hudoc.echr.coe.int/fre\#\{\%22sort\%22:[\%22EMPTY\%22 ],\%22itemid\%22:[\%22001-75345\%22]\}

19. Посібник зі статті 5 Право на свободу та особисту недоторканість. URL: https://www.echr.coe.int/Documents/ Guide_Art_5_UKR.pdf

\section{References:}

1. Convention for the Protection of Human Rights and Fundamental Freedoms of November 4, 1950. URL: https://zakon.rada.gov.ua/laws/show/995_004/ed19900101

2. Medvedyev and Others v. France. URL: https://sherloc.unodc.org/cld/case-law-doc/drugcrimetype/eu/2010/ medvedyev_and_others_v_france.html

3. Kurt v. Turkey. URL: https://www.refworld.org/cases,ECHR,49997ae512.html

4. Anguelova v. Bulgaria. URL: https://hudoc.echr.coe.int/fre\#\{\%22itemid\%22:[\%22001-81906\%22]\}

5. G. K. v. Poland. URL: https://hudoc.echr.coe.int

6. Talat Tepe v. Turkey. URL: https://www.gardencourtchambers.co.uk/wp-content/uploads/2015/09/CASE-OFKAYTAN-v.-TURKEY.pdf

7. Creangă v. Romania. URL: https://www.legal-tools.org/doc/fd9acb/pdf/

8. Włoch v. Poland. URL: https://swarb.co.uk/wloch-v-poland-no-2-echr-10-may-2011/

9. Baranowski v. Poland. URL: https://hudoc.echr.coe.int/fre\#\{\%22itemid\%22:[\%22001-82496\%22]\}

10. Svipsta v. Latvia. URL: https://hudoc.echr.coe.int/fre\#\{\%22itemid\%22:[\%2001-72749\%22]\}

11. Laumont v. France. URL: https://swarb.co.uk/laumont-v-france-echr-8-nov-2001/

12. Nasrulloyev v. Russia. URL: https://www.refworld.org/pdfid/473ac7512.pdf

13. Minjat v. Switzerland. URL: https://hudoc.echr.coe.int/fre\#\{\%22sort\%22:[\%22EMPTY\%22],\%22itemid\%22: [\%22001-65961\%22]\}

14. Khudoyorov v. Russia. URL: https://europeancourt.ru/resheniya-evropejskogo-suda-na-russkom-yazyke/xudoerovprotiv-rossii-postanovlenie-evropejskogo-suda/

15. Lloyd and Others v. the United Kingdom. URL: https://swarb.co.uk/lloyd-and-others-v-the-united-kingdom-echr1-mar-2005/

16. Stašaitis v. Lithuania. URL: https://brill.com/view/journals/hudi/13/3-4/article-p283.xml

17. Meloni v. Switzerland. URL: https://hudoc.echr.coe.int

18. 19.Ambruszkiewicz v. Poland. URL: https://hudoc.echr.coe.int/fre\#\{\%22sort\%22:[\%22EMPTY\%22],\%22item id\%22:[\%22001-75345\%22]\}

19. Article 5 The right to liberty and security of person. URL: https://www.echr.coe.int/Documents/Guide_Art_5_UKR.pdf 